$<$ 症例報告 $>$

造血幹細胞移植から 64 カ月後に投与されたスタチンが発症に関与したと 考えられた de novo B 型肝炎の 1 例

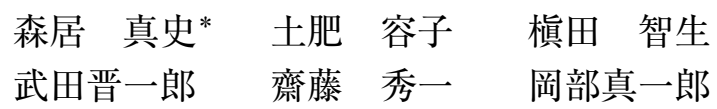

要旨：症例は 52 歳女性. 2008 年 12 月当院にて急性骨髄性白血病の診断. 移植目的に他院紹介 となり，2009年 6 月同種造血幹細胞移植が行われた．移植後，移植片対宿主病と一過性の肝胆 道系酵素異常が認められたがその後は著変なく, 同院にて半年ごとに経過観察されていた. 2014 年 10 月近医にて脂質異常症を指摘されロスバスタチンの内服治療が開始された. 1.5 カ月後の血 液検査で肝機能障害が認められ当科へ紹介. 来院時検査にて HBs 抗原陽性, IgM-HBc 抗体高力 価であることから急性 B 型肝炎と診断し保存的に加療した．核酸アナログ製剤は使用すること なく 1 カ月の経過で肝炎は沈静化し, 2.5 力月後に血中 HBV-DNA の消失を確認した. 後日他院 照会にて移植前検査において HBs 抗原陰性，かつ HBc 抗体および HBs 抗体陽性の既往感染者 であったことが判明し de novo B 型肝炎と最終診断した。

索引用語： de novo B型肝炎 スタチン 造血幹細胞移植Ｂ型肝炎ウイルス 再活性化

\section{はじめに}

近年，分子標的薬をはじめとした新規薬剤の登場や 使用機会の増加に伴い B 型肝炎ウイルス（hepatitis B virus；HBV)が再活性化し肝炎に至る病態が注目され ている. HBs 抗原陰性, かつ HBc 抗体ないし HBs 抗体 陽性の既往感染者において生じる肝炎は de novo B 型肝 炎と称され，多くは免疫抑制・化学療法の終了過程で 発症する.ひとたび劇症化すると致死率が高く ${ }^{1)}$, 予防 には定期的に血中 HBV-DNA モニタリングを行い, 検 出された時点で核酸アナログ製剤（nucleoside analogue；NA）を速やかに投与することが推奨されてい $る^{2)}$.

今回われわれは急性骨髄性白血病に対し同種造血幹 細胞移植 (allogeneic hematopoietic stem cell transplantation； allo-HSCT) が施行され，その 64 力月後に開始 された 3-hydroxy-3-methylglutaryl-CoA (HMG-CoA) 還 元酵素阻害薬，いわゆるスタチンが発症に関与したと 考えられる de novo B 型肝炎の1例を経験した. de novo

松戸市立病院消化器内科

*Corresponding author: amorii_0609@yahoo.co.jp $<$ 受付日2015年7月2日 $><$ 採択日2015年10月23日 $>$
B 型肝炎は血中 HBV-DNA が検出されるようになって から中央值 18.5 週という緩やかな経過で肝炎へ進展し ていくことが特徵とされるが2), 本症例では急性の発症 様式をもち，かつ NA 投与なしに速やかに改善が得ら れた。 またスタチンの関与が示唆された点は極めて特 異であり，貴重な症例と考えここに報告する．

\section{症例}

52 歳, 女性.

主訴：肝機能障害.

現病歴： 2008 年 12 月近医から貧血にて当院血液内科 へ紹介となり，精查の結果，急性骨髄性白血病の診断 となった. 移植目的に他院へ紹介され, イダルビシン + シタラビンにて寛解導入後, 2009 年 1 月よりミトキサ ントロン+シタラビン, 同年 3 月よりダウノルビシン + シタラビンにて地固め療法, 同年 6 月 HBV 未感染ドナー より骨髄提供を受け allo-HSCT が行われた．治療前検 查において HBs 抗原陰性，かつ $\mathrm{HBc}$ 抗体および HBs 抗体陽性であることが判明していたが血中 HBV-DNA は測定されることなく経過されていた。また本人や家 族には周知されていなかった. 移植後 Day10 に急性の 移植片対宿主病 (graft-versus-host disease；GVHD)を 
Table 1 Laboratory data on admission

\begin{tabular}{|c|c|c|c|c|c|}
\hline \multicolumn{6}{|c|}{$<\mathrm{CBC}>$} \\
\hline WBC & $43 \times 10^{3} / \mu l$ & $\gamma$-GTP & $186 \mathrm{IU} / l$ & ANA & $<40$ \\
\hline $\mathrm{RBC}$ & $459 \times 10^{4} / \mu l$ & $\mathrm{ChE}$ & $407 \mathrm{IU} / l$ & AMA-M2 & 1.7 \\
\hline $\mathrm{Hb}$ & $13.9 \mathrm{~g} / \mathrm{d} l$ & LAP & $148 \mathrm{IU} / l$ & $\operatorname{IgG}$ & $928 \mathrm{mg} / \mathrm{d} l$ \\
\hline $\mathrm{Ht}$ & $41.6 \%$ & CK & $70 \mathrm{IU} / l$ & $\operatorname{Ig} \mathrm{A}$ & $121 \mathrm{mg} / \mathrm{d} l$ \\
\hline \multirow[t]{2}{*}{ Plt } & $22.9 \times 10^{4} / \mu l$ & AMY & $93 \mathrm{IU} / l$ & $\mathrm{IgM}$ & $157 \mathrm{mg} / \mathrm{d} l$ \\
\hline & & $\mathrm{TP}$ & $6.9 \mathrm{~g} / \mathrm{d} l$ & & \\
\hline \multicolumn{2}{|c|}{$<$ Coagulation $>$} & Alb & $4.5 \mathrm{~g} / \mathrm{d} l$ & $<$ Viral marker $>$ & \\
\hline PT & $107.6 \%$ & $\begin{array}{l}\text { T.chol } \\
\text { TG }\end{array}$ & $\begin{array}{l}156 \mathrm{mg} / \mathrm{d} l \\
102 \mathrm{mg} / \mathrm{d} l\end{array}$ & $\begin{array}{l}\text { HBsAg (CLIA) } \\
\text { HBsAb }\end{array}$ & $>2250 \mathrm{IU} / \mathrm{m} l$ \\
\hline \multicolumn{2}{|c|}{$<$ Biochemistry $>$} & BUN & $12.3 \mathrm{mg} / \mathrm{d} l$ & HCVAb & $(-)$ \\
\hline T-bil & $0.82 \mathrm{mg} / \mathrm{d} l$ & Cre & $0.54 \mathrm{mg} / \mathrm{d} l$ & IgM-HBc Ab & 14 \\
\hline TTT & $1.6 \mathrm{KU}$ & $\mathrm{Na}$ & $143 \mathrm{mEq} / \mathrm{l}$ & IgM-HA Ab & $<0.4(-)$ \\
\hline ZTT & $4.0 \mathrm{KU}$ & $\mathrm{K}$ & $4.3 \mathrm{mEq} / \mathrm{l}$ & CMV IgM & $0.68(-)$ \\
\hline AST & $662 \mathrm{IU} / 1$ & $\mathrm{Cl}$ & $104 \mathrm{mEq} / \mathrm{l}$ & CMV IgG & $23.9(+)$ \\
\hline ALT & $1061 \mathrm{IU} / l$ & $\mathrm{Ca}$ & $9.4 \mathrm{mg} / \mathrm{d} l$ & EB VCA IgM & $0.0(-)$ \\
\hline LDH & $484 \mathrm{IU} / l$ & $\mathrm{CRP}$ & $<0.3 \mathrm{mg} / \mathrm{d} l$ & EB VCA IgG & $3.8(+)$ \\
\hline ALP & $577 \mathrm{IU} / 1$ & Glu & $94 \mathrm{mg} / \mathrm{d} l$ & EBNA & $4.7(+)$ \\
\hline
\end{tabular}

認めたがプレドニン増量にて対処され，またDay 17 には一過性の肝機能障害が認められたが速やかに改善 し, 以後肝胆道系酵素は基準值内で推移していた。 口 沿内乾燥, ドライアイなど慢性 GVHD 症状も認められ たが次第に改善し，服用中であったプレドニンおよび タクロリムスは漸減, 7 カ月後に中止となった. その後 半年㧍きに同院にて経過観察されていたが，移植治療 から 64 カ月経った 2014 年 10 月下旬, 近医を受診した 際に脂質異常症を指摘されロスバスタチンの内服治療 が開始された。開始前の肝機能はAST $18 \mathrm{U} / \mathrm{L}$, ALT $13 \mathrm{U} / \mathrm{L}$ と正常であったが, およそ 1.5 カ月後, AST 613 $\mathrm{U} / \mathrm{L}, \operatorname{ALT} 879 \mathrm{U} / \mathrm{L}$ と上昇を認め, 精査加療目的に当 科紹介. 即日入院となった.

既往歴：急性骨髄性白血病 (AML M2 相当).

服薬：ロスバスタチン (2014 年 10 月下旬から同年 12 月中旬まで).

家族歴：両親については不明. 同胞 (従妹)に HBV キャリア.

輸血歴：あり(AML 治療時).

生活歴：飲酒歴・刺青歴・鍼治療歴・ワクチン接種 歴いずれもなし．性的交渉はここ数年なし．海外渡航 歴なし.

入院時現症 : 身長 $161 \mathrm{~cm}$, 体重 $47.1 \mathrm{~kg}$, 血圧 131/77 $\mathrm{mmHg}$, 脈拍 64 回/分, 整, 体温 $37.0^{\circ} \mathrm{C}$. 意識清明.
眼球結膜に黄染なし，表在リンパ節は触知せず，腹部 は平坦，軟．肝脾は触知せず．神経学的所見に異常認 めず.

入院時血液検査所見 (Table 1)：AST $662 \mathrm{U} / \mathrm{L}, \mathrm{ALT}$ $1061 \mathrm{U} / \mathrm{L}$ とトランスアミナーゼ值の更なる上昇を認め た. ビリルビン，アルブミン，プロトロンビン時間は それぞれ T-bil $0.82 \mathrm{mg} / \mathrm{d} l, \mathrm{Alb} 4.5 \mathrm{~g} / \mathrm{d} l, \mathrm{PT} 107.6 \%$ と 肝予備能は保たれていた。 ウイルスマーカーは HBs 抗原陽性, HBs 抗体陰性. CMV と EBV は既感染パ夕ー ンを示し, HCV 抗体と IgM-HA 抗体は陰性であった。 自己抗体は ANA 陰性および AMA 陰性であった.

腹部超音波検査所見 (Fig. 1)：肝表面は整で腫大や 萎縮はなく，内部エコーは均一であったがわずかに脈 管輝度の上昇を認めた．脾腫や腹水はなく，胆囊の壁 肥厚や虚脱像はみられなかった。

経過：2008 年 12 月の当院血液内科受診時における検 査結果では HBs 抗原陰性 (HBc 抗体と HBs 抗体は未検) であった. 問診からはここ数年来, 性的接触歴はなく, また移植後は生食を一切していないとのことであった. サプリメントの愛用歴はなく, 家族歴の詳細は不明で あった。スタチンによる薬剤性肝障害や急性発症型自 己免疫性肝炎なども鑑別に挙げたが，今回の入院時検 查で HBs 抗原が陽転化していることから急性 B 型肝炎 を第一に考えた. 移植治療に伴い輸血歴を有すること 



Fig. 1 Abdominal ultrasonography on admission showed the slightly increased visibility of the portal vein wall. Hepatomegaly, splenomegaly, and ascites were not seen. In addition, a contracted gallbladder with a thickened wall was not demonstrated.

から非活動性キャリアからの急性増悪も考えられたが, 数日後に判明した IgM-HBc 抗体は $14.0 \mathrm{~S} / \mathrm{CO}$ と比較的 高值であり，その可能性は低いと思われた。感染経路 は不明であったが初感染の急性 B 型肝炎に矛盾しない 結果であった. 血中 HBV-DNA は $5.6 \log$ copies $/ \mathrm{ml}$ であった，肝予備能は保たれており全身状態も良好で あったが, 早期退院の希望が強く SNMC (stronger neominophagen C) $60 \mathrm{ml} /$ day を当初より使用した. さら にUDCA（ursodeoxycholic acid） $600 \mathrm{mg} /$ day を追加 投与し，およそ 2 週間の経過でAST $115 \mathrm{U} / \mathrm{L}$, ALT 289 U/L まで改善した. 第 15 病日に退院となり, 発症 から 1 力月後には HBs 抗原は陰性化し肝機能は正常に 復した. また 2.5 カ月後に血中 HBV-DNA は検出感度以 下となった (Fig. 2). その後, 移植治療を行った他院へ 照会したところ既往感染者であったことが判明し, de novo B 型肝炎と最終診断した. HBV genotype は type Cであり HBV 垂直感染が背景にあるものと思われた. 現在外来にて経過観察中であるが，慢性化することな く経過されている（Table 2).

\section{考察}

化学療法などを機に生じる HBV 再活性化や続発する 肝炎は HBV キャリアのみならず既往感染者においても 認められる病態である。これは免疫成立後もウイルス
が感染肝細胞の核内で完全二重鎖 DNA（covalently closed circular DNA ; cccDNA) となって潜伏感染して いることによる314)。再活性化および肝炎に至るまでの 詳細な機序は必ずしも明確になっていないが，化学療 法により招来される免疫抑制状態が cccDNA を起点と した HBV 複製を活発化させ, 治療終了に伴い免疫機構 が回復する過程で細胞障害性 T 細胞 (cytotoxic T lymphocyte；CTL)の活性が惹起され, 感染肝細胞の排除, すなわち肝炎に至ると考えられている4).

De novo B 型肝炎の臨床像は Hui らにより示された化 学療法終了後まず HBV-DNA の増殖が起こり, ここを 起点に中央值 10 週で HBs 抗原が陽転化し，その後中央 值 18.5 週 (12〜28 週) でALT 值が上昇する ${ }^{2)}$ という経 過が基本像として理解されている。 また劇症化すると 高い致死率を有することも特徵とされる ${ }^{11}$. しかし原疾 患や治療内容など患者背景によりその臨床像や転帰は 必ずしも一様ではない5). 本症例では, i) HSCT を背景 とし施行から 5 年以上 (64 カ月)が経過していること, ii) 短期間の内にトランスアミナーゼ值が急峻な立ち上 がりを示し，またNA 投与なしに重症化や慢性化する ことなく治療し得たこと, iii） IgM-HBc 抗体が高力価 陽性であったこと，などが特徵的であった。

HSCT 症例に扔ける HBV 再活性化については, HBs 抗原陽性例では $50 \%$ 以上に認められ, 既往感染例では 




Fig. 2 Clinical course after admission

Table 2 HBV serology after HSCT

\begin{tabular}{|c|c|c|c|c|c|c|c|c|}
\hline Date & Dec.-08 & Apr.-09 & Jun.-09 & & Dec.-14 & Jan.-15 & Mar.-15 & Jun.-15 \\
\hline HBsAg (CLIA) & $(-)$ & $(-)$ & $(-)$ & Our unit $\rightarrow$ & $>250.0$ & $(-)$ & $(-)$ & $(-)$ \\
\hline HBsAb & $>1000$ & 822.47 & 305.44 & & $(-)$ & $(-)$ & $(-)$ & 10.6 \\
\hline $\mathrm{HBeAg}$ & & 0.11 & 0.08 & (not available) & & 0.59 & & \\
\hline $\mathrm{HBeAb}$ & & 19.22 & 23.55 & & & 63 & & \\
\hline $\mathrm{HBcAb}$ & 78.34 & 80.11 & 82.27 & & & 8.99 & & 9.44 \\
\hline
\end{tabular}

14〜 50\% と報告されている ${ }^{6}$. 移植後から HBs 抗原陽 転化までの期間は中央值 23 力月（12 51 カ月) とされ る ${ }^{7)}$.リスク因子としては慢性 GVHD の併発 ${ }^{8)}$, 移植前 の $\mathrm{HBs}$ 抗体 $<10 \mathrm{mIU} / \mathrm{mL}^{9}$, 移植後の $\mathrm{HBs}$ 抗体価漸減 10 などが挙げられている.これは慢性 GVHD を併発する と免疫抑制剤の長期使用を余儀なくされることや，免 疫機構が置き換わるとレシピエント由来の HBs 抗体は 漸減していくことが背景にある. 本症例では慢性 GVHD の併発に加え, 移植後初期のみのデータであるが徐々 にHBs 抗体価は低下していた（Table 2).

HSCT 後における HBV の再活性化は移植された免疫 機構の成熟度と関係していると考えられ，多くは移植 して間もない 1,2 年の内に起こる. しかし時に本症例 のような長期経過例を認める。 その理由の一つとして
Schubert らは移植前 HBs 抗体が高力価であると再活性 化が遅延することを挙げている ${ }^{11}$. しかし肝炎の発症メ カニズムを考えると抗体のプールのみでは十分とはい えない.

これまでに HBV の持続感染や肝炎の進展には, 抑制 性 T 細胞 (regulatory T cell ; Treg)の量的あるいは機 能的不均衡が関係していることが報告されている1213). Tregは免疫寛容や恒常性維持において過剩な免疫応答 が起こらないようにエフェクター T 細胞や CTLを制御 している CD4 陽性ヘルパー T 細胞の一種であるが'4), de novo B 型肝炎においても Treg をはじめ免疫学的不 均衡が病態に関わっているものと考えられる. 実際, Kowazaki らは急性骨髄性白血病に対し HSCT を施行し た de novo B 型肝炎症例において免疫学的解析を行い, 


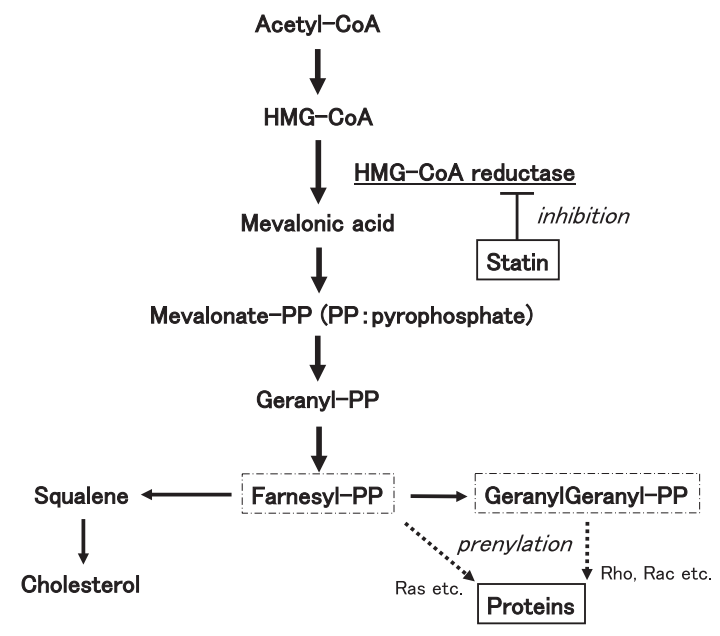

Fig. 3 Mevalonate metabolic pathway

移植から 5 カ月後に血中 HBV-DNA の検出に一致して Treg が減少し, HBV 特異的 CTL が増加していたこと を観察している(1). 長期経過例においては, いかにそう した不均衡が生じ得るのであろうか. われわれは発症 前に投与されたスタチンに着目してみた.

スタチンは脂質異常症に対する治療薬として国内外 で広く使用されている薬剤であるが, 血清コレステロー ル低下作用以外に抗酸化作用，血管内皮細胞機能の改 善作用，抗炎症作用など多面的作用 (pleiotropic effect) を有することが判明している ${ }^{16)}$.また心臓移植術後の患 者においてスタチン投与群で移植後の拒絶反応が有意 に低率であったことが示され年，免疫抑制作用をもつこ とでも注目されている.

スタチンによって阻害されるメバロン酸代謝経路の 下流には, 蛋白の翻訳後修飾（プレニル化）に必要な ファルネシルピロリン酸やゲラニルゲラニルピロリン 酸といったイソプレノイドを合成する経路がある(Fig 3). 翻訳後修飾とはイソプレノイドがもつ疎水性のイ ソプレニル基を蛋白に付加する脂質修飾のことである が，これにより蛋白の細胞膜への結合が促進され細胞 内における局在や活性が制御されている. Rho, Ras, Rab など低分子量 GTP 結合蛋白をはじめ, 多くの蛋白 がプレニル化により調節を受けている。 スタチンによ るイソプレノイドの合成阻害が蛋白のプレニル化を阻 み, 多面的作用を生み出すと考えられている ${ }^{16)}$.

免疫抑制機序については, ひとつに Treg を分化誘導 することが示されている ${ }^{1819)}$.このことはスタチンが免
疫抑制剂として作用し得ることを示唆しており, 実際, 慢性関節リウマチ患者において疾患活動性を抑制する ことが確認されている ${ }^{19)}$.しかし一方でこの効果は抗炎 症作用によるとする報告もみられ ${ }^{20}$, 多面的作用をもつ 故の複雑さがある．機序の詳細については不明な点も あるが，これまでの多くの報告から強固とはいえない までも免疫抑制作用を併せ持つことは確かである ${ }^{21)}$.

改めて本症例を振り返ってみると, NA 投与なしに重 症化することなく治癒し得た経過はとりもなおさず免 疫機構が正常に機能していたことを意味している。つ まり移植された免疫機構はすでに成熟し安定期にあっ たと考えられる。一般に de novo B 型肝炎の発症には, 免疫抑制状態と, 続く機能回復という二つの過程を要 するが，長期経過し安定期にあった本症例が肝炎に至 るには免疫に対し抑制的に働く何らかの付加的因子を 想定するのが妥当であると思われる。 また短期間の内 に肝機能障害を呈し沈静化した経過からは，免疫抑制 の程度が限定的であり, かつ速やかに機能回復したこ とが示唆される. HBs 抗体が漸減する中, スタチンの 穏やかな免疫抑制作用が加わり発症に至ったと考える ことに大きな矛盾はない.

残念ながら本症例では HSCT 後から継続して HBV 血清マーカーが測定されていないため再活性化の正確 な起点を示すことができない. よってスタチンが直接 の契機となったかは論じ得ないが, 最近Rodríguez-Perea らにより興味深い報告がなされた ${ }^{22}$. 著者らは健常ボラ ンティア 18 人を対象にスタチンを 45 日間服用させた ところ, 開始 30 日目に Tregが上昇し，45 日目に基線 に戻ったという結果を報告している，単純に解釈すれ ば，これは一定期間免疫抑制状態が続いた後，自然解 除されることを意味している。本症例ではスタチンの 服用から 1.5 力月後に肝炎を発症しているがまさにその 経過と符合する。.さらなる検討は必要だが本症例にお けるスタチンの関与を支持するものである.

これまでにスタチンの関与を示した HBV 再活性化に ついての報告は 1 例23)のみであるが(PubMedにて statin, reactivation, virus を keywordに検索), 脂質異 常症治療薬としてのカラーが強いスタチンに拈いては 見過ごされている可能性もある，通常スタチンを処方 するにあたっては, HBV マーカーまで検討することは 極めて少ない，必要の是非については今後の検証を待 ちたいが，本症例のように特定の既往歴をもつ場合に は留意すべきである．専門医のみならず多くの医師に とって処方機会のある薬歳に拈いて, このような一考 
すべき症例があることを喚起すべくここに報告した 結語

造血幹細胞移植から 64 カ月後に発症した de novo B 型肝炎の 1 例を経験した. 発症要因としてスタチンの 関与が示唆された，スタチンは血清コレステロール低 下作用のみならず多面的作用をもつ薬剤であり，その 潜在する作用には注意が必要である.

\section{文 献}

1) Umemura T, Tanaka E, Kiyosawa K, et al. Mortality secondary to fulminant hepatic failure in patients with prior resolution of hepatitis B virus infection in Japan. Clin Infect Dis 2008; 47: 52—56

2) Hui CK, Cheung WW, Zhang HY, et al. Kinetics and risk of de novo hepatitis B infection in HBsAgnegative patients undergoing cytotoxic chemotherapy. Gastroenterology 2006; 131: 59-68

3) Fong TL, Di Bisceglie AM, Gerber MA, et al. Persistence of hepatitis $\mathrm{B}$ virus DNA in the liver after loss of HBsAg in chronic hepatitis B. Hepatology 1993; 18: 1313-1318

4) Rehermann B, Ferrari C, Pasquinelli $C$, et al. The hepatitis $\mathrm{B}$ virus persists for decades after patients' recovery from acute viral hepatitis despite active maintenance of a cytotoxic T-lymphocyte response. Nat Med 1996; 2: 1104-1108

5）梅村武司. 本邦に扔ける de novo B 型肝炎症例の背 景と予後. 最新医学 $2013 ; 68: 351-354$

6) Knöll A, Boehm S, Hahn J, et al. Reactivation of resolved hepatitis B virus infection after allogeneic haematopoietic stem cell transplantation. Bone Marrow Transplant 2004; 33: 925—929

7) Kempinska A, Kwak EJ, Angel JB, et al. Reactivation of hepatitis $\mathrm{B}$ infection following allogeneic bone marrow transplantation in a hepatitis Bimmune patient: case report and review of the literature. Clin Infect Dis 2005; 41: 1277-1282

8) Seth P, Alrajhi AA, Kagevi I, et al. Hepatitis B virus reactivation with clinical flare in allogeneic stem cell transplants with chronic graft-versus-host disease. Bone Marrow Transplant 2002; 30: 189-194

9) Hammond SP, Borchelt AM, Ukomadu C, et al. Hepatitis $\mathrm{B}$ virus reactivation following allogeneic hematopoietic stem cell transplantation. Biol Blood Marrow Transplant 2009; 15: 1049—1059
10) Onozawa M, Hashino S, Izumiyama K, et al. Progressive disappearance of anti-hepatitis B surface antigen antibody and reverse seroconversion after allogeneic hematopoietic stem cell transplantation in patients with previous hepatitis B virus infection. Transplantation 2005; 79: 616-619

11) Schubert A, Michel D, Mertens T. Late HBsAg seroreversion of mutated hepatitis B virus after bone marrow transplantation. BMC Infect Dis 2013; 13: 223

12) Aalaei-Andabili SH, Alavian SM. Regulatory T cells are the most important determinant factor of hepatitis B infection prognosis: a systematic review and meta-analysis. Vaccine 2012; 30: 55955602

13) Chen Y, Fang J, Chen X, et al. Effects of the Treg/ Th17 cell balance and their associated cytokines in patients with hepatitis B infection. Exp Ther Med 2015; 9: 573-578

14) Sakaguchi S, Ono M, Setoguchi R, et al. Foxp3+ $\mathrm{CD} 25+\mathrm{CD} 4+$ natural regulatory $\mathrm{T}$ cells in dominant self-tolerance and autoimmune disease. Immunol Rev 2006; 212: 8-27

15) Kowazaki Y, Osawa Y, Imamura J, et al. Immunological analysis of a patient with hepatitis B virus (HBV) reactivation after bone marrow transplantation. Intern Med 2015; 54: 1213-1217

16) Greenwood J, Steinman L, Zamvil SS. Statin therapy and autoimmune disease: from protein prenylation to immunomodulation. Nat Rev Immunol 2006; 6: 358-370

17) Kobashigawa JA, Katznelson S, Laks H, et al. Effect of pravastatin on outcomes after cardiac transplantation. N Engl J Med 1995; 333: 621—627

18) Mausner-Fainberg K, Luboshits G, Mor A, et al. The effect of HMG-CoA reductase inhibitors on naturally occurring $\mathrm{CD} 4+\mathrm{CD} 25+\mathrm{T}$ cells. Atherosclerosis 2008; 197: 829-839

19) Tang TT, Song Y, Ding YJ, et al. Atorvastatin upregulates regulatory $\mathrm{T}$ cells and reduces clinical disease activity in patients with rheumatoid arthritis. J Lipid Res 2011; 52: 1023-1032

20) McCarey DW, McInnes IB, Madhok R, et al. Trial of Atorvastatin in Rheumatoid Arthritis (TARA): double-blind, randomised placebo-controlled trial. Lancet 2004; 363: 2015—2021 
21) Forero-Peña DA, Gutierrez FR. Statins as modulators of regulatory T-cell biology. Mediators Inflamm 2013; 2013: 167086

22) Rodríguez-Perea AL, Montoya CJ, Olek S, et al. Statins increase the frequency of circulating CD4+ FOXP3 + regulatory T cells in healthy individuals.
J Immunol Res 2015; 2015: 762506

23) Wu du C. Hepatitis B virus reactivation associated with atorvastatin. Int J Infect Dis 2013; 17: 10691070

\title{
A case of de novo hepatitis B associated with statin administered at 64 months later following allogeneic hematopoietic stem cells transplantation
}

\author{
Shinji Morii*, Yoko Doi, Tomoo Makita, \\ Shinichiro Takeda, Shuichi Saito, Shinichiro Okabe
}

A 52-year-old female who was diagnosed with acute myeloid leukemia underwent allogeneic hematopoietic stem cells transplantation (allo-HSCT) in June 2009. She developed acute and chronic graft-versus-host disease after allo-HSCT, being monitored every half a year without requiring any therapy afterwards. In October 2014, she was admitted to our hospital because of showing elevated serum transaminase levels 1.5 months later after prescription of rosuvastatin for dyslipidemia. HBV serology showed hepatitis B surface antigen-positive and high IgM-hepatitis B core antibody titer, which raised the suspicion of acute hepatitis B. Her liver function improved to baseline values in one month without using the nucleoside analogue, confirming disappearance of serum HBV-DNA 2.5 months later. It was revealed that she had a history of resolved HBV infection prior to transplantation therapy. In conclusion she was diagnosed with de novo hepatitis B probably induced by rosuvastatin. Key words: de novo hepatitis B statin allogeneic hematopoietic stem cells transplantation hepatitis $\mathrm{B}$ virus reactivation

Kanzo 2015; 56: 661—667

Department of Gastroenterology, Matsudo City Hospital

*Corresponding author: amorii_0609@yahoo.co.jp

(C) 2015 The Japan Society of Hepatology 